\title{
GROWTH PATTERN STUDY OF SLENDER WALKING CATFISH (Clarias nieuhofii) AS ENVIRONMENTAL BIOLOGY INDICATOR
}

\author{
Helentina Mariance Manullang ${ }^{1}$, Khairul ${ }^{2 *}$ \\ ${ }^{1}$ Aquaculture Programme, Universitas Dharmawangsa, Jl. KL Yos Sudarso No.224 Glugur Kota, \\ Medan City, Sumatera Utara Province, Indonesia \\ ${ }^{2}$ Biology Education Programme, Universitas Labuhanbatu, Jl. Sisingamangaraja No.126-A, km 3,5 \\ Aektapa, Rantauprapat City, Labuhanbatu Regency, Sumatera Utara Province, Indonesia \\ *Email: khairulbiologi75@gmail.com
}

Doi: https://doi.org/10.31943/mangiferaedu.v5i1.97

Received: May 15, $2020 \quad$ Accepted: July 25, $2020 \quad$ Published: July 31, 2020

Citation: Manullang, H. M., \& Khairul. (2020). Growth Pattern Study of Slender Walking Catfish (Clarias nieuhofii) as Environmental Biology Indicator. Jurnal Mangifera Edu, 5(1), 1-7.

\begin{abstract}
Slender walking catfish (Clarias nieuhofii) is a consumption fish that has a fairly high economical value. Local market prices can reach IRD 50.000-70.000/kg. People love this fish because of the delicious taste of the meat, which very different from the aquaculture catfish. Until now the production relies only on natural catches and there have been no cultivation efforts. But in recent years these out catfish are increasingly difficult to find in nature. The conversion of land into plantation areas caused the loss of the fish's original habitat. Based on community information, the habitat of this fish is found in Pasir Putih Village, Silangkitang District, Labuhan Batu Selatan Regency, and Bandar Tinggi Village, Bilah Hulu District, Labuhanbatu Regency, Indonesia. Differences in habitat conditions are known to affect fish growth patterns, including $C$. nieuhofii. This research aims to determine the pattern of the growth of the slender walking catfish in these different habitat conditions. Exploratory methods were used in this research and observation stations were determined through purposive sampling. Fish sampling was done using a fishing rod. The samples of fish captured were measured by the total length and weight. The results of the research show that the pattern of fish growth in Pasir Putih Village is negative allometric $\left(W=0.6944, b=0.2463\right.$ and $\left.R^{2}=0.9468\right)$ and in Bandar Tinggi Village shows negative allometric $\left(W=10.207, b=-129.56\right.$, and $\left.R^{2}=0.9711\right)$.
\end{abstract}

Keywords: Clarias nieuhofii, growth pattern, indicator biology

\section{INTRODUCTION}

The Famous catfish commonly consumed by people are slender walking catfish $(C$. nieuhofii). This fish is popular because it has a good taste image and has a thick flesh (Muttakin, 2018). C. nieuhofii has several local names in Indonesia such as Keli (Kepulauan Bangka Belitung), Limbek (Kampar, Riau), Lembat (Jambi and Sumatra Utara), Kaleh (Kalimantan), and Lindi (Jawa Barat, Jawa Tengah, and Jakarta). In plain English is called slender walking catfish. C. nieuhofii commands a higher market price compared to other 
Clarias (Pechsiri \& Vanichanon, 2016). IUCN data by Ng (2019), C. nieuhofii is regarded as 'critically endangered' in Singapore (Lim et al., 2008).

C. nieuhofii is classified as a catfish that is characterized by the dorsal fins and the anus (anal) extending and united with the tail fin, at least on its base. Dorsal fin with 87-106 soft fingers, anal fin 63-93 soft fingers (Kottelat et al., 1993). One type of catfish that is commonly consumed by the community is slender walking catfish ( $C$. nieuhofii). This fish is favored by society because it has a good taste image and has a thick flesh (Muttakin, 2018). C nieuhofii is widespread in Southeast Asia including in the Malay Peninsula, Indonesia (Java, Sumatra, and Kalimantan), Singapore, Thailand, and the Philippines (Kottelat et al., 1993; Lim et al., 2008; Pechsiri \& Vanichanon ,2016).

In Kepulauan Bangka Belitung Province at the local level, only the price of this fish can reach $\$ 2.7-3.7 / \mathrm{kg}$ (Muttakin, 2018). C. nieuhofii price is more expensive when compared to the aquaculture catfish. At the Glugur market in Rantauprapat City, Labuhanbatu Regency, the price of $C$. nieuhofii can reach $\$ 3.37-4.7 / \mathrm{kg}$. However, $C$. nieuhofii has begun to be difficult to obtain in nature. Based on community information, this is due to land conversion, arrest using toxins, and electrical fish and insecticide in plantation land (Personal Interview, 2020) According to Pechsiri \& Vanichanon (2016) population and the density of the walking catfish has decreased significantly over the last two decades, mainly because of over-exploitation, reduction in habitat areas as a result of peat swamp forest reclamation, and unwise insecticide applications in the rice fields.

Based on information from the habitat community C. nieuhofii is still found in several locations in Labuhan Batu Selatan Regency (Pasir Putih Village) and Labuhanbatu Regency (Bandar Tinggi Village). But so far it has not been known bioecological conditions. Research related to bioecology of $C$. nieuhofii is still very little in Indonesia, whereas this fish is a genuine germplasm Indonesia.

One important study was about the growth pattern of this fish, remember the information about it is still very rare to find. Hopefully, this research data can be the key information for stakeholders to make the management efforts of the C. nieuhofii genetic resources in the study area. The potential genetic power of $C$. nieuhofii needs to be utilized wisely to keep its sustainability intact.

\section{RESEARCH METHODS}

Fish sampling was carried out in January, February, and March 2020, so there were three samples taken at each observation station. Observation Station 1 is located in Pasir 
Jurnal Mangifera Edu, Volume 5, Nomor 1, Juli 2020, 1-7

Putih Village, Silangkitang District, Labuhan Batu Selatan Regency, and observation Station 2 in Bandar Tinggi Village, Bilah Hulu District, Labuhanbatu Regency. Furthermore, taking the coordinates of the point to make a map of research locations using the Global Positioning System (GPS). Station $1\left(1^{0} 48^{\prime} 23.880\right.$ N 99052'30.98 E), is a natural habitat that has been switched into palm oil plantation and Station $2\left(2^{0} 0^{\prime} 54.29 \mathrm{~N} \mathrm{99} 52^{\prime} 40.68 \mathrm{E}\right)$, is a natural habitat that has switched function into a bathing tour. The research map can be seen in Figure 1.

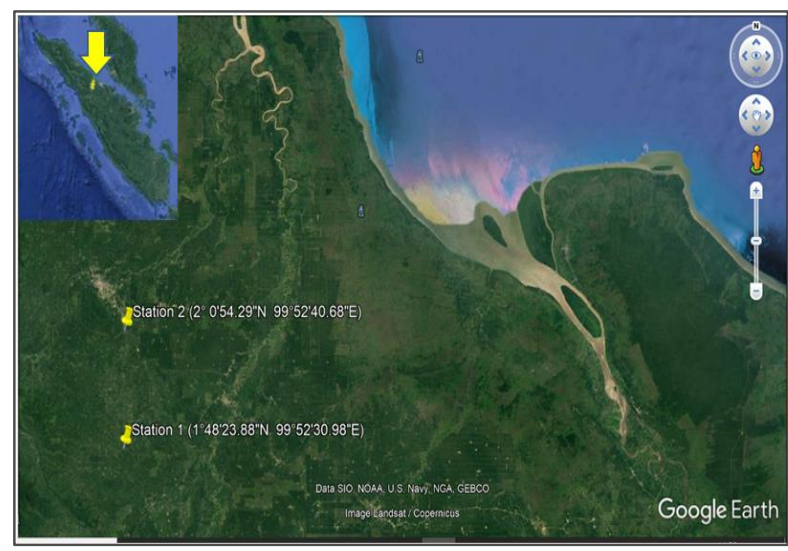

Figure 1. Map of Observation Station

Sampling using fishing rods with worm bait. Fish caught during the day, at $9.00-$ 15.00 WIB and night, at 19.00-22.00 WIB. All samples of fish caught in total length measurements by using a standard ruler $30 \mathrm{~cm}$ long and for a total weight measured by a scale with $0.01 \mathrm{~g}$ accuracy. Growth patterns of fish calculated using the formula (Effendie, 1979):

$$
\mathrm{W}=\mathrm{aL}^{\mathrm{b}}
$$

Description: $\mathrm{W}=$ total weight $(\mathrm{g}), \mathrm{L}=$ total length $(\mathrm{cm})$, $\mathrm{a}$ and $\mathrm{b}=$ constants.

Data of research results created in the form of data tabulation for subsequent processing of data using Microsoft Excel application 2010. The research results are made in exponential curve-shaped graphs.

\section{RESULTS AND DISCUSSION}

The number of fish samples caught at Station 1 as many as 25 individuals. $C$. nieuhoffii growth pattern Data analysis results in Pasir Putih Village with value $\mathrm{W}=0.69$, B $=0.25$ and ${ }^{\mathrm{R} 2}=0.95$ or $95 \%$, which means the data analysis results show highly significant $(\mathrm{P}>0.05)$. 


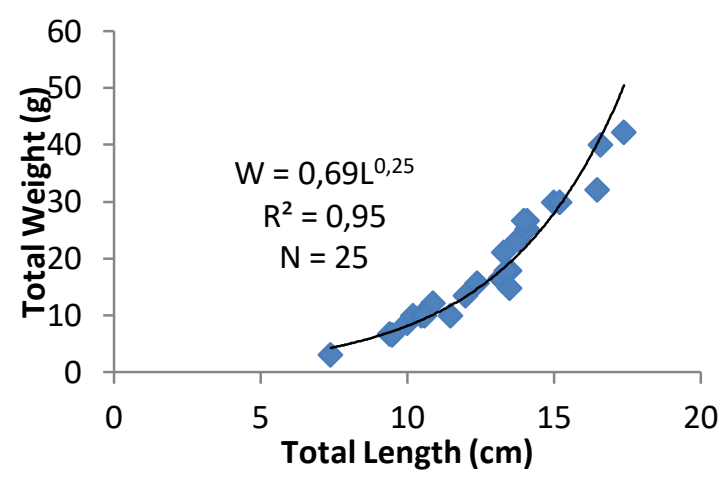

Figure 2. C. nieuhofii Growth Pattern in Pasir Putih Village

The number of fish samples caught at Station 2 [c46] as many as 25 individuals. Based on data analysis shows the growth pattern of $C$. nieuhofii in Bandar Tinggi village Value $\mathrm{W}=10.21, \mathrm{~B}=-129.56$, and $\mathrm{R}^{2}=0.97$ or $97 \%$, means the data analysis results show highly significant $(\mathrm{P}>0.05)$.

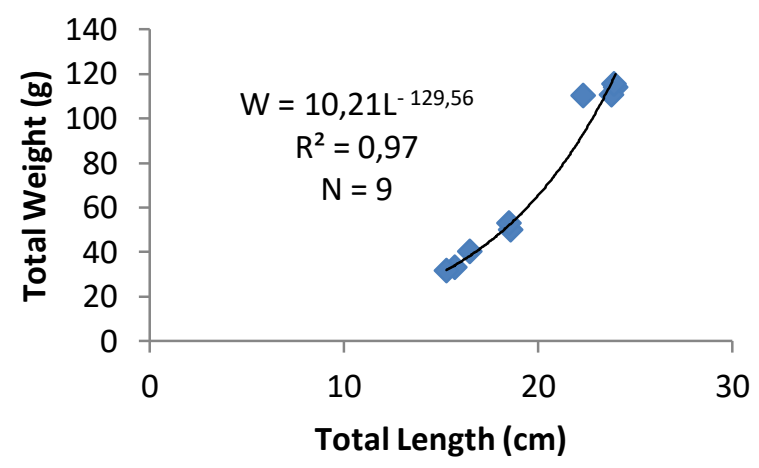

Figure 3. C. nieuhofii Growth Pattern in Bandar Tinggi Village

Based on the data analysis result is known that the value $b$ on station $1(0,25)$ and station 2 (-129.56). On both observation stations obtained $b$ value of $<3$. According to Effendie (1979) if the $b$ value of $<3$ indicates the growth pattern is negative allometric. Determination coefficient $\left(\mathrm{R}^{2}\right)$ on Station 1 is 0,95 , describing the diversity of data by $94.68 \%$, while at Station 2 of 0.97 or $97.11 \%$. The value of $\mathrm{R}^{2}$ approaching 1 means it has a strong correlation. The $\mathrm{R}^{2}$ value of Station 1 of 0.95 interpreted that a $94.68 \%$ weight increase of $\mathrm{C}$ nieuhofii is influenced by total length increase. At Station 2 It was so, the $\mathrm{R}^{2}$ value obtained by 0.97 or $97.11 \%$ of fish weight increase was influenced by total length. The length-weight relationship for the five treatments were 3.3, 3.03, 3.0, 2.9 and 2.7 with corresponding coefficient of determination $\left(\mathrm{R}^{2}\right)$ values of $0.8313,0.9517,0.9629,0.9223$, and 0.8726. T4 and T5 exhibited a negative allometric growth pattern (Olapade \& Conteh, 2019). 
According to Santana et al., (2016) standard length Iheringichthys labrosus (Lütken, 1874) varied from 6.0 to $20.5 \mathrm{~cm}$. Growth showed negative allometry for both sexes. Negative allometric growth pattern, where the total length of body size increase faster than the weight increase of fish (Barrata et al., 2019). But when the growth of fish is isometric indicates that there is a balance between the length and weight of fish (Nurhayati et al., 2016; Faizah \& Anggawangsa, 2019). The results of the research related to some patterns of fish growth as comparison, can be seen in table 1 .

Table 1. Comparative Research Results Based on Variation Value Constants b of Fish Growth Pattern

\begin{tabular}{ccccc}
\hline Species & b Value & Growth pattern & Lacation & References \\
\hline Gerres oyena & $5,436 \sigma^{\lambda}$ & Positive & Tondonggeu & Sarfila et al., 2018 \\
& $5,291 q$ & allometric & Waters & \\
Chlorurus & 2,5877 & Negative & Wakatobi & Patanda \& Rahmani, \\
strongycephalus & & allometric & Waters & 2018 \\
Labiobarbus & $3,284 \delta$ & Isometric & Tulang & Yudha et al., 2015 \\
ocellatus & $3,272 q$ & & Bawang River & \\
\hline
\end{tabular}

Long and heavy variables in fish growth patterns are known to have strong relationships (Suwarni, 2009). Overexploitation through arrest by fishermen may affect the long-heavy fish (Suruwaky \& Gunaisah, 2013). Muchlisin (2010) states that the small value of $b$ is influenced by the behavior of fish, such as active swimming fish shows a lower $b$ value when compared to a passive swimming fish. The different views of growth patterns can be caused by environmental conditions as well as the biological condition of catfish. Another strong suspicion is because of the aquatic conditions capable of supporting the life of fish quite well (Sihaloho et al, 2017). The growth pattern of fish as aquatic organisms certainly varies, depending on the environmental conditions and availability of food utilized to support its sustainability and growth (Nikolsky, 1963). In the field of long biological analysis, fisheries are one of the factors that need to be known, because it relates to the management of fishery resources. Fish growth Data can provide information about the production of a type of fish (Sasmito et al., 2016; Sihaloho et al., 2017). Moreover, the long analysis of fish weight is carried out as a biological indicator of the condition of the aquatic ecosystem (Courtney et al., 2014).

\section{CONCLUSION}

The pattern of the growth of $C$. nieuhofii in both fields of study is negative allometric, meaning the increase in body length faster than body weight. This indicates that the environment as a living habitat $C$. nieuhofii in a stable condition. Based on the results of 
Jurnal Mangifera Edu, Volume 5, Nomor 1, Juli 2020, 1-7

field observations need to know $C$. nieuhofii species is a type of catfish that loves the clear water habitat and pollution-free.

\section{REFERENCE}

Barrata, Yanti, A. H., \& Setyawati, T. R. (2019). Pola Pertumbuhan Ikan Peam (Leptobarbus melanopterus) di Taman Nasional Danau Sentarum Kabupaten Kapuas Hulu. Protobiont, 8(1), 1 - 5.

Courtney, Y., Courtney , J., \& Courtney , M. (2014). Improving weight-length relationship in fish to provide more accurate bioindicators of ecosystem condition. Aquatic Science and Technology, 2(2).

Effendie, M. I. (1979). Metoda Biologi Perikanan. Yogyakarta: Yayasan Pustaka Nusantara.

Faizah, R., \& Anggawangsa, R. F. (2019). Hubungan panjang bobot, parameter pertumbuhan, dan faktor kondisi ikan gulamah Johnius carouna (Cuvier, 1830) di Perairan Selatan Jawa. Jurnal Iktiologi Indonesia, 19(2), 231-241.

Lim, K. K., Tan, H. H., \& Low, J. K. (2008). Fishes (2nd ed.). (G. W. Davison, P. K. Ng, \& H. H. Chew, Eds.) Singapore: Nature Society.

Muchlisin, Z. A. 2010. Biodeversity Of Freshwater Fishes In Aceh Province, Indonesia With Emphasis On Several Biological Aspects Of The Depik (Rasbora Tawarensis) An Endemic Species In Lake Laut Tawar. Dissertation. Penang: Universiti Sains Malaysia.

Muttakin, I. 2018. Induksi Maturasi Ikan Keli Lokal Jantan (Clarias nieuhofii) Menggunakan Hormon GnRH Analog + Antidopamin. Thesis. Balunijuk Bangka: Universitas Bangka Belitung.

Ng, H. H. 2012. Slender Walking Catfish (Clarias nieuhofii). Retrieved Mei 16, 2019, from IUCN Redlist: https://www.iucnredlist.org/species/181236/1712229

Nikolsky, G. V. 1963. The Ecology of Fishes. London: Academic Press.

Nurhayati, Fauziyah, \& Bernas, S. M. 2016. Hubungan Panjang-Berat Ikan dan Pola Pertumbuhan Ikan Di Muara Sungai Musi Kabupaten Banyuasin Sumatera Selatan. Maspari Journal, 8(2), 111-118.

Olapade, O. J., \& Conteh, K. U. (2019). Growth Performance, Length - Weight Relationship and Condition Factor of Clarias gariepinus Fed Anisophyllea laurina Seed Meal Substitute. J. Appl. Sci. Environ. Manage., 23(3), 505-511.

Patanda, M., \& Rahman, U. 2018. Hubungan Panjang-Berat dan Pola Pertumbuhan Ikan Kakatua (Chlorurus strongycephalus) Di Taman Nasional Wakatobi. Jurnal Teknologi Perikanan dan Kelautan, 9(2), 115 - 121. 
Jurnal Mangifera Edu, Volume 5, Nomor 1, Juli 2020, 1-7

Pechsiri, J., \& Vanichanon., A. 2016. Genetic Diversity in Slender Walking Catfish (Clarias nieuhofii) Populations: Implications for Population Management. Walailak J Sci \& Tech, 13( 7), 511-519.

Santana, H. S., Rodrigues, A. C., \& Tos, C. D. (2016). Patterns of reproduction and growth of the catfish Iheringichthys labrosus (Lütken, 1874) after a reservoir formation. Journal Applied Ichthyology, 32(3), 456-463.

Sarfila, Halili, \& Arami, H. 2018. Pertumbuhan dan hubungan panjang berat Ikan Kapaskapas (Gerres oyena) di Perairan Tondonggeu Kecamatan Abeli Kota Kendari. Jurnal Manajemen Sumber Daya Perairan, 3(2), 135-142.

Sasmito, H., Nur, A. I., \& Abdullah. 2016. The growth pattern of Ponyfish (Leiognathus Eguulus) in Kendari Bay at Southeast of Sulawesi Province. Jurnal Manajemen Sumber Daya Perairan, 1(3), 275-284.

Sihaloho, P. S., Sitorus, H., \& Leidonald, R. 2017. Kinds of Fish Species and Growth Pattern of Fish that was Chaught at River Seruai, Namo Suro Village, Deli Serdang District of North Sumatera. Aquacoastmarine, 5(2), 127-136.

Siregar, Rijes. (2020, January 11). Personal interview.

Suruwaky, A. M., \& Gunaisah, M. 2013. Identifikasi Tingkat Eksploitasi Sumber Daya Ikan Kembung Lelaki (Rastrelliger kanagurta) Ditinjau dari Hubungan Panjang Berat. Jurnal Akuatika, 4(2), 131-140.

Suwarni. 2009. Hubungan Panjang-Bobot dan Faktor Kondisi Ikan Butana Acanthurus mata (Cuvier, 1829) yang Tertangkap di Sekitar Perairan Pantai Desa Mattiro Deceng, Kabupaten Pangkajene Kepulauan, Provinsi Sulawesi Selatan. Torani (Jurnal Ilmu Kelautan dan Perikanan), 19(3), 160-165.

Kottelat, M., Whitten, A. J., Kartikasari, S., \& Wirjoatmodjo, S. (1993). Fresh-Water Fishes of Western Indonesia and Sulawesi.

Yudha, I. G., Rahardjo, M. F., Djokosetiyanto, D., \& Lumban Batu, D. T. 2015. Pola Pertumbuhan dan Faktor Kondisi Ikan Limo Labiobarbus ocellatus (Heckel, 1843) Di Sungai Tulang Bawang, Lampung. Zoo Indonesia, 24(1), 29-39. 